\title{
Metabolic Profiling of Normal and Lame Karan Fries Cows and its Association with Lameness during Transition Period
}

\author{
Pragya Bhadauria $^{1 *}$, S.S. Lathwal ${ }^{2}$, Y.S. Jadoun ${ }^{3}$ and Rohit Gupta ${ }^{4}$ \\ ${ }^{1}$ ICAR-Agricultural Technology Application Research Institute, Ludhiana, INDIA \\ ${ }^{2}$ ICAR-National Diary Research Institute, Karnal, INDIA \\ ${ }^{3}$ Guru Angad Dev Veterinary and Animal Sciences University, Ludhiana, INDIA \\ ${ }^{4}$ Punjab Agriculture University, Ludhiana, INDIA \\ *Corresponding author: P Bhadauria; E-mail: pragyacari@gmail.com
}

Revised: 15 April, 2020

Accepted: 20 April, 2020

\begin{abstract}
In high yielding dairy cows, one of the major cause of lameness during transition period is the altered nutritional status of pregnant animal. Concentrations of essential nutrients get varied and often decrease around calving due to physiological factors and thus extra-supplementation is recommended in these animals. Blood measures are frequently used in assessment of the vital nutrients for predicting the risk of lameness during this period. The objective of this study was to investigate the nutritional status of healthy and lame Karan Fries (KF) cows and their association with lameness score during transition period. For this fifteen high-yielding crossbreed (KF) healthy cows and fifteen high yielding crossbreed (KF) lame cows were randomly selected from the Livestock Research Centre (LRC) of National Diary Research Institute, Karnal for pooled blood sample collection. Samples were collected $60 \mathrm{~d}, 15 \mathrm{~d}$ pre-partum, on the day of calving, and $60 \mathrm{~d}, 15 \mathrm{~d}$ post-partum. The results revealed that the mean plasma biotin, zinc (below critical level) and calcium (within range) levels were significantly lower $(\mathrm{P}<0.05)$ in lame $\mathrm{KF}$ cows while $\beta$-hydroxybutyrate (BHBA) concentrations was significantly higher, however no significant difference in plasma copper, glucose and non-esterified fatty acids (NEFA) concentrations was found in lame cows as compared to normal KF cows during this period. There was also significant $(\mathrm{P}<0.05)$ variation of blood biochemical profiles (glucose, NEFA and BHBA) and plasma biotin concentration among different lameness scores (1-5) whereas no relation of mineral profiles (calcium, zinc and copper) was seen with lameness score.
\end{abstract}

Keywords: Lameness, transition period, nutrient deficiency, blood metabolites

Though the modern husbandry and management conditions have increased the milk production but all at the cost of higher incidences of health problems. The highproducing dairy cows are always at the verge of abnormal homeostasis.

The breeding and feeding of dairy cattle for high milk yields is etiologically related to various metabolic disease common in these animals (Sharma and Upadhyay, 2009). One of the major challenges for dairy producers is to maintain hoof health of high yielder's during the transition period. Now a day, lameness is one of the most important welfare issues of high producing dairy cows (Eicher et al., 2013). The economic importance of lameness is reported as attributable to impaired reproductive performance (Sogstad et al., 2006), decreased milk production (Green et al., 2010 and Green et al., 2002), culling from the herd (Sprecher et al., 1997), and cost of treatment and control methods (Hernandez and Shearer 2000, Moore 2001). In various studies it was found that the incidence of lameness within 30 days postpartum was $2.2 \%$ (Melendez et al., 2003), between 3.5 and $6 \%$ during the first 30 days of lactation (Collik et al., 1989) and a high percentage

How to cite this article: Bhadauria, P., Lathwal, S.S., Jadoun, Y.S. and Gupta, R. (2020). Metabolic profiling of normal and lame Karan fries cows and its association with lameness during transition period. J. Anim. Res. 10(3): 375-382.

Source of Support: None; Conflict of Interest: None 
of $65 \%$ occurred during the first 100 days postpartum (Grohn et al., 1990) which may be considered as sequel to parturition. In different states of India, its incident has been reported from $20.5 \%$ to $69.6 \%$ in Holstein crossbred cows (Ganpule 1987; Maiti et al., 1996; Singh et al., 1998).

It is well known that nutrition can have a dramatic impact on the incidence of lameness. Nutritional status of pregnant animal plays a major role in determining variations in circulating blood metabolite and other nutrients concentration during transition period. Their concentrations often decrease around calving and extrasupplementation is recommended in some dairy herds. As transition period is always associated with tremendous serial changes in nutritional, biochemical and hormonal status from late gestation to early lactation. Physiological changes coupled with high milk production is a risk factor for lameness (Barkema et al., 1994; Deluyker et al., 1991; Rowlands et al., 1986) during this period impose considerable challenge to homeostasis by altering normal metabolism and production of stressors. The changes impacted by hormones, vitamins, minerals, and trace elements and the roles they play in development of quality claw horn tissue predispose the animal towards subclinical/clinical lameness in later stages.

Early detection and prevention of lameness in down calvers could be important both from the economic point of view and for animal welfare (Hirst et al., 2002). For this blood measures are frequently used in assessment of metabolic disorders as serum mineral-vitamin and metabolites concentrations suggest a diagnostic capacity to predict possible disease risk. Use of pooled samples collected from predefined physiological groups, and testing a wide array of analytes, have been advocated as a practical and economic method of screening the dairy herd for periparturient disease risk (Van Saun, 2006). For this a series of specific analytical tests run in combination and used as a diagnostic aid in order to evaluate disease risk in contrast to disease diagnosis (Ingraham and Kappel, 1998). Key diagnostic analytes identified as predictive for lameness during transition period includes glucose, nonesterified fatty acids (NEFA), $\beta$-hydroxybutyrate (BHBA), calcium, zinc, copper and biotin (LeBlanc, 2010; Ospina et al., 2010a and Chapinal et al., 2011).

As the amount of research examining the effect of transition nutrition on the lameness is limited as well as data related metabolic profiles of lame-crossbreed cattle is scanty. To bridge the above mentioned gap, the present study was planned to estimate the blood biochemical and mineral-vitamin profiles of lame Karan Fries cows.

\section{MATERIALS AND METHODS}

\section{Experimental design and procedure}

The present study was conducted on transition period (two months before and two months after calving) of Karan Fries (KF) cows maintained at Livestock Research Centre (LRC), National Diary Research Institute Karnal, Haryana. Fifteen high yielding crossbreed (KF) normal cows and fifteen high yielding crossbreed (KF) lame cows were randomly selected from the institute herd and grouped into healthy and lame. All the selected animals were in their last trimester of pregnancy aged between of 3-7 years with average weight between $400-500 \mathrm{~kg}$ and having an average lactation yield up to $4000 \mathrm{~kg}$. All cows were fed with the same ration as formulated according to NRC (2001) recommendations and no treatment diet was given to the lame animals. They were offered ad-libitum green fodder and concentrate mixture@1.0 kg for every $2.5 \mathrm{~kg}$ milk production, (above $5.0 \mathrm{~kg}$ milk yield) in addition to $1.5 \mathrm{~kg}$ for maintenance measured. The concentrate mixture has $20 \% \mathrm{CP}$ and $70 \% \mathrm{TDN}$ consists of $33 \%$ maize, $21 \%$ GNC (Oiled), 12\% mustard cake (oiled), 20\% wheat bran, $11 \%$ de-oiled rice bran, $2 \%$ mineral mixture containing essential minerals and $1 \%$ common salt. Pooled blood samples were collected through jugular venipuncture using blood collection tubes with heparin as anticoagulant early in the morning (7.00 to $8.00 \mathrm{am}$ ) before feeding. Samples were collected $60 \mathrm{~d}, 15 \mathrm{~d}$ pre-partum, on the day of calving, and $60 \mathrm{~d}, 15 \mathrm{~d}$ post-partum. Immediately after collection the blood samples were centrifuged at $3000 \mathrm{rpm}$ for 15 to 20 minutes, plasma were separated and stored in cryovials of $2 \mathrm{ml}$ capacity at $-20^{\circ} \mathrm{C}$ until analysis.

\section{Estimation of key diagnostic metabolites/nutrients}

The selected key diagnostic metabolites/nutrients identified as predictive for lameness during transition includes; analytes reflecting energy balance viz. glucose, nonesterified fatty acids (NEFA), $\beta$-hydroxybutyrate (BHBA); minerals like calcium $(\mathrm{Ca})$, zinc $(\mathrm{Zn})$ and copper $(\mathrm{Cu})$ and vitamin biotin were measured by following protocols. The blood biochemical parameters viz., glucose was estimated 
by end point O-Toluidine method, plasma NEFA was estimated by copper soap extraction method modified by Shipe et al. (1980) and BHBA was estimated using $\beta$-HB Assay Kit (Bio Vision, USA, Catlog\#k632-100) in the experimental animals. Plasma minerals mainly $\mathrm{Ca}, \mathrm{Zn}$ and $\mathrm{Cu}$ were estimated with the help of Atomic Absorption Spectrophotometer (Model Z-5000, Polarized Zeeman Atomic absorption Spectrophotometer, Hitachi HighTechnologies Corporation, Tokyo, Japan). The procedure described in AAS (1988) manual for preparation of stock and standard solutions and choice of instrumental conditions were followed. Biotin was quantitatively determined by enzyme immunoassay (Avidin-binding substances) Vitamin H ELISA kit (MDBioscience, St Paul, MD, USA; Cat\# M046019). From the test results, averages for each metabolite were calculated for both the groups of lame and healthy animals.

\section{STATISTICAL ANALYSIS}

Data were expressed as means \pm standard error. Data for all measured variables were analyzed as two way ANOVA to find significant difference between groups and their interaction by using SYSTAT 3.1 (2004) software. Significance among the mean values was tested using Duncan's multiple range test at $\mathrm{p}<0.05$. The correlations among the various parameters were also calculated (Snedecor and Cochran, 1994).

\section{RESULTS AND DISCUSSION}

Blood metabolites, biotin and mineral status in lame and normal KF cows during transition period

The blood metabolites, biotin and minerals status in lame and normal KF cows during transition period is presented in Table 1. In lame cows biotin was significantly lower $(\mathrm{P}<0.05)$ compared to normal cows $(354.91 \pm 23.22 \mathrm{vs}$. $799.625 \pm 34.35 \mathrm{ng} / \mathrm{L}$, respectively). The above results reveals that a significant lower serum biotin concentration in the lame cows during transition period is in conjunction with the findings of Higuchi et al. (2003). Similarly, Bhadauria et al., 2012; Lawrence et al., 2008; Hedges et al., 2001; Midla et al., 1998; Roberts and Baggott (1982) reported that lactating dairy cows with a history of lameness have been found to have lower plasma biotin levels when compared with cows with no history of lameness and studies have shown that orally administered biotin raises plasma (Zinn et al., 1987) and milk (Frigg et al., 1992) biotin levels in dairy cows.

In general, biotin is synthesized in the rumen in varying amounts depending on the composition of the diet, although during peri-parturient period the ruminal synthesis of biotin by bacteria may be compromised by an acidic condition of the rumen due higher concentrate diets (Dacosta et al., 1998). Hence, lack of sufficient biotin in their rumen to convert lactic acid to pyruvate and then oxaloacetate predisposes the animals to lactic acidosis which in turn produces the endotoxin that releases in the blood and affects the hoof structure. Nocek (1997) also reported that lactic acidosis as one of the possible contributing factors in lameness of dairy cows. Such conditions can occur in the periparturient period and in early lactation (Blowey et al., 2000; Da Costa et al., 1998; Roberts and Baggot, 1982). Secondly, Minoccheri et al. (1977) found an inverse correlation between the concentration of biotin in the serum and in the milk during lactation as water soluble vitamins from the serum are transported to mammary gland during dry period to prepare for coming lactation which also leads to lower level of biotin content in serum. Thus a lower biotin concentration in serum due to loss of biotin in the milk and production of endo-toxin during lactation makes the hoofs more susceptible to lameness in its early stages (Minoccheri et al., 1977). However the mechanism underlying the changes in serum biotin in cows is yet not very clear.

Similarly, mean plasma zinc concentration in the cows with lameness was significantly lower than in the healthy cows $(0.34 \pm 0.05$ vs. $1.26 \pm 0.09$ ppm, respectively). Insufficient supplies of bioavailable zinc and subsequent lower plasma concentration during the periparturient period may predispose cows to production of inferior horn tissue, with a concomitant increase in lameness.

In lame cows plasma calcium was significantly lower $(\mathrm{P}<0.05)$ compared to normal cows $(10.72 \pm 0.29$ vs. $11.52 \pm 0.27 \mathrm{mg} / \mathrm{dl}$, respectively). However plasma copper content was found to be non significantly lower in lame cows $(0.911 \pm 0.10 \mathrm{ppm})$ compared to normal cows $(1.15 \pm 0.12 \mathrm{ppm})$. Van Saun et al. (2005) reported that healthy cows had higher plasma mineral concentrations pre- and postpartum compared to diseased cows which is in agreement with present study. Similarly mean zinc 
and copper concentration in the cows with lameness was significantly lower than in the control animals (Kilic et al., 2007). Baggott et al. (1988) also found that the concentration of zinc in the hoof horn of lame cows was lower than in healthy animals.

In present study, $\beta$-hydroxybutyrate (BHBA) was significantly higher $(\mathrm{P}<0.05)$ in lame cows compared to normal cows $(767.10 \pm 24.91$ vs $601.1 \pm 30.62 \mu \mathrm{mol} / 1$, respectively). Similarly, non-esterified fatty acids (NEFA) concentration was calculated to be non significantly higher in lame cows compared to normal cows $(142.27 \pm 5.45$ vs. $123.22 \pm 8.49 \mu \mathrm{mol} / 1$, respectively). Glucose concentrations was estimated to be non significantly lower in lame cows as compared with normal cows (142.27 \pm 5.45 and $62.58 \pm 2.42 \mathrm{mg} / \mathrm{dl}$, respectively).

Table 1: Concentration of blood metabolites, biotin and minerals in lame and normal KF cows

\begin{tabular}{llll}
\hline $\begin{array}{l}\text { Sl. } \\
\text { No. }\end{array}$ & Parameters & Lame cows & Normal cows \\
\hline 1 & Biotin $(\mathrm{ng} / \mathrm{L})$ & $354.91 \pm 23.22^{\mathrm{a}}$ & $799.62 \pm 34.35^{\mathrm{b}}$ \\
2 & $\mathrm{Zn}(\mathrm{ppm})$ & $0.34 \pm 0.05^{\mathrm{a}}$ & $1.26 \pm 0.09^{\mathrm{b}}$ \\
3 & $\mathrm{Cu}(\mathrm{ppm})$ & $0.911 \pm 0.10^{\mathrm{a}}$ & $1.15 \pm 0.12^{\mathrm{a}}$ \\
4 & $\mathrm{Ca}(\mathrm{mg} / \mathrm{dl})$ & $10.72 \pm 0.29^{\mathrm{a}}$ & $11.52 \pm 0.27^{\mathrm{b}}$ \\
5 & $\mathrm{Glucose}(\mathrm{mg} / \mathrm{dl})$ & $60.93 \pm 2.98^{\mathrm{a}}$ & $62.58 \pm 2.4^{2} \mathrm{a}$ \\
6 & $\mathrm{BHBA}(\mu \mathrm{mol} / \mathrm{l})$ & $767.10 \pm 24.91^{\mathrm{a}}$ & $601.1 \pm 30.62^{\mathrm{b}}$ \\
7 & $\mathrm{NEFA}(\mu \mathrm{mol} / \mathrm{l})$ & $142.27 \pm 5.4^{5} \mathrm{a}$ & $123.22 \pm 8.49^{\mathrm{a}}$ \\
\hline
\end{tabular}

a, b-significance difference $(\mathrm{P}<0.05)$.

Association of lameness score with different blood biochemical, mineral and biotin profiles of KF cows during transition period

The association of lameness score with different blood biochemical, minerals and biotin profiles during the experimental period is depicted in Table 2. The result revealed significant $(\mathrm{P}<0.05)$ variation of blood biochemical profiles and plasma biotin concentration among different lameness score and non significant variation of mineral profiles and glucose level was found in KF cows with different lameness score. The plasma biotin content significantly reduced $(\mathrm{P}<0.05)$ as the lameness score increased from 1 to 5 and the highest concentration was found in cows with lameness score $1(776.58 \pm 46.32$ $\mathrm{ng} / \mathrm{L}$ ) whereas, lowest concentration of plasma biotin was found in the cows with lameness score 5 (335.59 \pm 53.61 $\mathrm{ng} / \mathrm{L})$.
Many studies suggested that dairy cows fed additional organic zinc, exhibited fewer cases of hoof disorders (Demertizis, 1973; Moore et al., 1989). Nobijariaet al. (2012) reported that there has been lower days of recovery to lameness and improved claw condition and hoof hardness. Although, no effect of zinc supplementation was found on locomotion score in Jersey cows during the two weeks before and after parturition. Griffiths et al. (2007) also found no effect of supplementation minerals on claw hardness or on the incidence of claw disorders. Even if a beneficial effect of the mineral supplementation was observed in the locomotion score, these scores of locomotion are not clinically relevant.

Blood BHBA and NEFA concentration varied significantly $(\mathrm{P}<0.05)$ among cows with different lameness scorein present study. The lowest concentration of BHBA was found in cows with lameness score $1(639.75 \pm 27.66$ $\mu \mathrm{mol} / \mathrm{l})$ whereas highest concentration with lameness score $5(736.95 \pm 19.59 \mu \mathrm{mol} / 1)$. Similarly, NEFA concentration was observed to be lowest in cows with lameness score $1(105.88 \pm 8.95 \mu \mathrm{mol} / \mathrm{l})$ whereas highest concentration with lameness score $5(140.25 \pm 9.03 \mu \mathrm{mol} / \mathrm{l})$. As glucose transported into the mammary gland in high-yielding dairy cows during early lactation while the feed intake is insufficient to cover the requirements for energy (Blum et al., 1983; Aeberhard et al., 2001). This decrease in glucose availability in plasma, leads to increased plasma NEFA and BHBA level. Long chain fatty acids mobilized from adipose tissues are a major source of energy to the cow during this period (Goff and Horst, 1997). In case of lame cows the energy balance is much more disturbed leads to higher values of NEFA and BHBA but within the physiological limits (Dann et al., 2006; Douglas et al., 2006; Janovick et al., 2011). With the increase in lameness score and its intensity, the lame animal spend much more time in lying and resting rather than eating leads to more higher values of NEFA and BHBA (Bauman and Currie, 1980; Baird, 1982; Herdt, 2000). Margerison et al. (2002) also reported that animal suffering from lameness, the lying time got increased which causes a functionally reduced access to feed.

\section{Overall correlation between different parameters}

The overall correlation among blood biochemical, biotin and minerals is presented in Table 3. The biotin 
Table 2: Association of lameness score with different blood biochemical, mineral and biotin profiles of KF cows during transition period

\begin{tabular}{llllll}
\hline \multirow{2}{*}{ Parameter } & \multicolumn{5}{c}{ Lameness score } \\
\cline { 2 - 6 } & $\mathbf{1 ( n = 1 5 )}$ & $\mathbf{2}(\mathbf{n}=\mathbf{2 0})$ & $\mathbf{3 ( n = 2 5 )}$ & $\mathbf{4}(\mathbf{n}=\mathbf{1 0})$ & $\mathbf{5}(\mathbf{n}=\mathbf{5})$ \\
\hline Biotin $(\mathrm{ng} / \mathrm{l})$ & $776.58 \pm 46.32^{\mathrm{a}}$ & $675.52 \pm 52.03^{\mathrm{ab}}$ & $458.14 \pm 37.66^{\mathrm{b}}$ & $409.122 \pm 17.56^{\mathrm{b}}$ & $335.59 \pm 53.61^{\mathrm{b}}$ \\
$\mathrm{Zn}(\mathrm{ppm})$ & $1.25 \pm 0.08^{\mathrm{a}}$ & $1.051 \pm 0.128^{\mathrm{a}}$ & $1.04 \pm 0.09^{\mathrm{a}}$ & $0.91 \pm 0.10^{\mathrm{a}}$ & $0.83 \pm 0.25^{\mathrm{a}}$ \\
$\mathrm{Cu}(\mathrm{ppm})$ & $1.15 \pm 0.03^{\mathrm{a}}$ & $1.14 \pm 0.03^{\mathrm{a}}$ & $1.073 \pm 0.081^{\mathrm{a}}$ & $1.04 \pm 0.06^{\mathrm{a}}$ & $1.03 \pm 0.05^{\mathrm{a}}$ \\
$\mathrm{Ca}(\mathrm{mg} / \mathrm{dl})$ & $11.456 \pm 0.175^{\mathrm{a}}$ & $11.36 \pm 0.16^{\mathrm{a}}$ & $11.33 \pm 0.46^{\mathrm{a}}$ & $11.17 \pm 0.15^{\mathrm{a}}$ & $10.87 \pm 0.18^{\mathrm{a}}$ \\
$\mathrm{Glucose}(\mathrm{mg} / \mathrm{dl})$ & $59.37 \pm 1.12^{\mathrm{a}}$ & $58.435 \pm 2.636^{\mathrm{a}}$ & $56.75 \pm 1.93^{\mathrm{a}}$ & $55.86 \pm 1.23^{\mathrm{a}}$ & $54.67 \pm 3.22^{\mathrm{a}}$ \\
$\mathrm{BHBA}(\mu \mathrm{mol} / \mathrm{l})$ & $639.75 \pm 27.66^{\mathrm{a}}$ & $655.06 \pm 13.62^{\mathrm{a}}$ & $684.06 \pm 32.52^{\mathrm{ab}}$ & $689.25 \pm 14.76^{\mathrm{ab}}$ & $736.95 \pm 19.59^{\mathrm{b}}$ \\
NEFA $(\mu \mathrm{mol} / \mathrm{l})$ & $105.88 \pm 8.95^{\mathrm{a}}$ & $123.16 \pm 10.44^{\mathrm{ab}}$ & $125.28 \pm 19.86^{\mathrm{ab}}$ & $134.97 \pm 10.60^{\mathrm{ab}}$ & $140.25 \pm 9.03^{\mathrm{b}}$ \\
\hline
\end{tabular}

a, b-significance difference $(\mathrm{P}<0.05)$ within row.

Table 3: Overall correlations among blood metabolites, biotin and minerals

\begin{tabular}{llllllll}
\hline Parameters & Biotin & Zinc & Copper & Calcium & Glucose & BHBA & NEFA \\
\hline Biotin & 1 & & & & & & \\
Zinc & $0.364^{* * *}$ & 1 & & & & & \\
Copper & $0.304^{* * *}$ & -0.065 & 1 & & & \\
Calcium & -0.068 & $0.446^{* * *}$ & $-0.185^{* *}$ & 1 & & & \\
Glucose & 0.028 & $0.378^{* * *}$ & -0.076 & $0.392^{* * *}$ & 1 & & \\
BHBA & 0.069 & $-0.439^{* * *}$ & $0.220^{* *}$ & $-0.516^{* * *}$ & $-0.531^{* * *}$ & 1 & \\
NEFA & -0.029 & $-0.423^{* * *}$ & $0.240^{* * *}$ & $-0.486^{* * *}$ & $-0.517^{* * *}$ & $0.622^{* * *}$ & 1 \\
\hline
\end{tabular}

$*, * *, * * *$ indicates significance at $5 \%, 1 \%$ and $0.1 \%$, respectively.

was positively and significantly correlated with $\mathrm{Zn}(\mathrm{r}$ $=0.364, \mathrm{P}<0.001)$ and $\mathrm{Cu}(\mathrm{r}=0.304, \mathrm{P}<0.01)$ showing a synergistic effect with zinc and copper in hoof health improvement. If we look at the association of serum biotin concentration and its affect on lameness score, it is clearly indicated from the results that an inverse relation was found between plasma biotin concentration and intensity of lameness in the present study. Similar findings were also reported by Fitzgerald et al. (2000), Hoblet and Weiss (2001) and Bergsten and Mulling (2004) where the biotinsupplemented herds exhibited better locomotion scores than the unsupplemented herds. As biotin is possibly the vitamin of greatest importance to the keratinization process. It plays an important role in differentiation of the epidermal cells that will become the hoof horn. More recently, biotin supplementation has also been reported to stimulate the production of intracellular cementing substance (ICS) that bond horn cells and harden the horn tissue. Several studies have shown that biotin can increase horn quality and promote horn formation (Hochstetter, 1998; Higuchi and Nagahata, 2001) and thus increase hoof resistance (Midlaet al., 1998; Campbell et al., 2000; Fitzgerald et al., 2000) and improve healing (Lischer et al., 1996) of claw lesions in cattle.

Although $\mathrm{Zn}$ was negatively but not-significantly correlated to $\mathrm{Cu}(\mathrm{r}=0.065)$. $\mathrm{Zn}$ was positively and significantly correlated with $\mathrm{Ca}(\mathrm{r}=0.446, \mathrm{P}<0.001)$ and glucose $(\mathrm{r}=0.378, \mathrm{P}<0.001)$, whereas negatively and significantly correlated with BHBA $(r=-0.439, \mathrm{P}<0.001)$ and NEFA $(r=-0.423, P<0.001)$. Similar finding was reported by Zhang et al. (2010). It is perceived that trace minerals have beneficial effects on oxidative stress and inflammation that can be help to increase overall health and epithelial tissue integrity while reducing the energy required to maintain these systems and consequently improving available energy (Nayeri et al., 2014).Cu was positively and significantly correlated with BHBA $(\mathrm{r}=0.220, \mathrm{P}<0.01)$ and NEFA $(\mathrm{r}=0.240, \mathrm{P}<0.001)$ and negatively correlated with $\mathrm{Ca}(\mathrm{r}=-0.185, \mathrm{P}<0.01)$. Ca was positively and significantly correlated with glucose $(\mathrm{r}=$ $0.392, \mathrm{P}<0.001)$ and negatively correlated with BHBA ( $\mathrm{r}$ $=-0.516, \mathrm{P}<0.001)$ and NEFA $(\mathrm{r}=-0.486, \mathrm{P}<0.001)$. The 
plasma mineral concentrations are very dynamic around the time of calving as homeostatic mechanisms are altered to facilitate transition into lactation. Due to excessive lactation stress and decreased immunity coupled with environmental and managemental conditions disturbed the homeostatic controls and unable to maintain normal physiologic mineral concentrations. Reports have shown a depression in the blood levels of calcium (Ca), zinc ( $\mathrm{Zn})$ during the periparturient period (Johnston and Chew 1984, Goff and Stabel, 1990).

Glucose was negatively and significantly associated with BHBA $(r=-0.531, \mathrm{P}<0.001)$ and NEFA $(r=-0.517$, $\mathrm{P}<0.001)$. While BHBA was positively and significantly associated with NEFA $(\mathrm{r}=0.622, \mathrm{P}<0.001)$.

\section{CONCLUSION}

In high yielding dairy animals with lameness, there is considerable decrease in the concentration of nutrients like glucose, biotin, zinc and calcium with the simultaneous increase in the values of BHBA and NEFA concentrations compared to normal cows. Similarly, with decrease in glucose availability in plasma, NEFA and BHBA can be considered as parameters for determining energy balance in the animal body and can be taken as indicators of negative energy balance in the body (NEB) which predisposes the animals towards metabolic disease risk. From the present study it is assumed that macro and trace minerals plays an important role in minimizing lameness through their roles in production of horn tissue, and the maintenance of epithelial and connective tissue in dairy animals. Minimizing the incidence of lameness during transition can only be accomplished by supplying diets with adequate energy content, preventing the incidence of subclinical hypocalcemia and feeding increased levels of trace minerals and vitamins reduce the incidence of lameness in later lactation in high yielding dairy cows.

\section{REFERENCES}

Aeberhard, K.I., Bruckmaier, R.M. and Blum, J.W. 2001. Metabolic, enzymatic and endocrine status in high-yielding dairy cows-Part 2. J. Vet. Med., 48: 111-127.

Barkema, H.W., Westrik, J.D., Van Keulen, K.A.S., Schukken, Y.H. and Brand A. 1994. The effects of lameness on reproductive performance, milk production and culling in Dutch Dairy Farms. Prev. Vet. Med., 20: 249-259.
Blowey, R.W., Phipps, R.A., Jones, K. and Barringer, A.J. 2000. A comparison of the effects of high fibre and high starch diets on hoof lesion score in multiparous dairy cows. In: Proceedings of $\mathrm{XI}^{\text {th }}$ International Symposium on Disorders of the Ruminant Digit and III International Conference on Bovine Lameness, pp. 337-339

Baggott, D.G., Bunch, K.J. and Gill, K.R. 1988. Variations in some inorganic components and physical properties of claw keratin associated with claw disease in the British Friesian cow. Brit. Vet. J., 144: 534-542.

Baird, G.D. 1982. Primary ketosis in the high-producing dairy cow: clinical and subclinical disorders, treatment, prevention, and outlook. J. Dairy. Sci., 65: 1-10.

Bauman, D.E. and Currie, W.B. 1980. Partitioning of nutrients during pregnancy and lactation: A review of mechanisms involving homeostasis and homeorhesis. J. Dairy. Sci., 63: 1514-1529.

Bergsten, C. and Mulling Ch. K.W. 2004. Some reflections on research on bovine laminitis - aspects of clinical and fundamental research. In: Proceedings of the $13^{\text {th }}$ International Symposium on Lameness in Ruminants. Maribor/Slovenia. pp: 53-60.

Bhadauria, Pragya., Lathwal, S.S., Jadoun, Y.S. and Bhadauria, S.S. 2012. Role of Biotin in Prevention of Lameness in Dairy Cattle-Review. Wayamba J of Anim Sci., pp. 635-646.

Blum, J.W., Kunz, P.L., Leuenberger, H., Gautschi, K. and Keller, M. 1983. Thyroid hormones, blood plasma metabolites and haematological parameters in relationship to milk yield in dairy cows. Anim. Prod., 36: 93-104.

Chapinal, N., Carson, M., Duffield, T.F., Capel, M., Godden, S., Overton, M., Santos, J.E.P. and LeBlanc, S.J. 2011. The association of serum metabolites with clinical disease during the transition period. J. Dairy Sci., 94: 4897-4903.

Collik, D.W., Ward., W.R. and Dobson, H. 1989. Associations between types of lameness and fertility. Vet. Rec., 125: 103106.

Campbell, J.R., Greenough, P.R., and Petrie, L. 2000. The effects of dietary biotin supplementation on vertical fissures of the claw wall in beef cattle. Can. Vet. J., 41: 690-694.

DaCosta Gomez, C., Al Masri, M., Steinberg, W. and Abel, H.J. 1998. Effect of varying hay/barley proportions on microbial biotin metabolism in the rumen simulating fermenter (RUSITEC). In: Proceedings of Society of Nutrition Physiology 7 (Abstr.).

Dann, H.M., Litherland, N.B., Underwood, J.P., Bionaz M., D'Angelo D., McFadden J.W. and Drackley, J. K. 2006. Diets during far-off and close-up dry periods affect periparturient metabolism and lactation in multiparous cows. J. Dairy Sci., 89: $3563-3577$. 
Demertizis, P.N. 1973. Oral zinc therapy in the control of infectious pododermatitis in young bulls. Vet. Rec., 93: 219222.

Deluyker, H.A., Gay, J.M., Weaver, L.D. and Azari, A.S. 1991. Change of milk yield with clinical diseases for a high producing dairy herd. J. Dairy Sci., 74: 436-445.

Douglas, G.N., Overton, T.R., Bateman II, H.G., Dann, H.M. and Drackley, J.K. 2006. Prepartal plan of nutrition, regardless of dietary energy source, affects periparturient metabolism and dry matter intake in Holstein cows. J. Dairy Sci., 89: 21412157.

Eicher, S.D., Lay D.C., Jr Arthington, J.D. and Schutz, M.M. 2013. Effects of rubber flooring during the first 2 lactations on production, locomotion, hoof health, immune functions, and stress. J. Dairy Sci., 96: 3639-3651.

Fitzgerald, T., Norton, B.W., Elliot, R., Podlich, H. and Svendsen, O.L. 2000. The influence of long-term supplementation with biotin on the prevention of lameness in pasture fed dairy cows. J. Dairy Sci., 83:3 38-344.

Frigg, M., Straub, O.C. and Hartmann, D. 1992. The bioavailability of supplemental biotin in cattle. Int. J. Vitam. Nutr. Res., 63: 122- 128.

Ganpule, S.P. 1987. Seasonal incidence of major health problems in an exotic herd. Indian J. Anim. Hlth., 26: 69-71.

Goff, J.P. and Horst, R.L. 1997. Effects of the addition of potassium or sodium, but not calcium, to prepartum rations on milk fever in dairy cows. J. Dairy Sci., 80: 176-186.

Goff, J.P. and Stabel, J.R. 1990. Decreased plasma retinol, alphatocopherol, and zinc concentration during the periparturient period: effect of milk fever. J. Dairy Sci., 73: 3195-9.

Green, L.E., Hedges, V.J., Schukken, Y.H., Blowey, R.W. and Packington, A.J. 2002. The impact of clinical lameness on the milk yield of dairy cows. J. Dairy Sci., 85: 2250-2256.

Green, L.E., Borkert, J., Monti G. and Tadich, N. 2010. Associations between lesion-specific lameness and the milk yield of 1635 dairy cows from seven herds in the $\mathrm{X}^{\text {th }}$ region of Chile and implications for management of lame dairy cows worldwide. Anim. Welf., 19: 419-427.

Griffiths, L.M., Loeffler, S.H., Socha, M.T., Tomlinson, D.J. and Johnson, A.B. 2007. Effects of supplementing complexed zinc, manganese, copper and cobalt on lactation and reproductive performance of intensively grazed lactating dairy cattle on the South Island of New Zealand. Anim. Feed. Sci. Tech., 137: 69-83.

Grohn, Y.T., Erb, H.N., McCulloch, C.E. and Saloniemi, H.S. 1990. Epidemiology of reproductive disorders in dairy cattle: associations among host characteristics. Prev. Vet. Med., 8: 25-39.
Hedges, J.1., Blowey, R.W., Packington, A.J., O’ Callaghan, C.J and Green, L.E. 2001. A longitudinal field trial of the effect of biotin on lameness in dairy cows. J. Dairy Sci., 84(9): 196975.

Herdt, T.H. 2000. Ruminant adaptation to negative energy balance. Influences on the etiology of ketosis and fatty liver. Vet. Clin. North Am. Small Anim. Pract., 16: 215-30.

Hernandez, J. and Shearer, J.K. 2000. Efficacy of oxytetracycline for treatment of papillomatous digital dermatitis lesions on various anatomic locations in dairy cows. J. Am. Vet. Med. Assoc., 216: 1288-1290.

Higuchi, H. and Nagahata, H. 2001. Relationship between serum biotin concentration and moisture content of the sole horn in cows with clinical laminitis or sound hooves. Vet. Rec., 148: 209-210.

Higuchi, H., Maeda, T., Kawai, K., Kuwano, A., Kasamatsu, M. and Nagahata, H. 2003. Physiological changes in the concentrations of biotin in the serum and milk and in the physical properties of the claw horn in Holstein cows. Vet. Res. Commun., 27: 407-413.

Hirst, W.M., Murray, R.D., Ward, W.R. and French, N.P. 2002. A mixed effects time-to-event analysis of the relationship between first-lactation lameness and subsequent lameness in dairy cows in the UK. Prev. Vet. Med., 54: 191-201.

Hoblet, K.H. and Weiss, W. 2001. Metabolic hoof horn disease, Claw horn disruption. Vet. Clin. N. Am-Food A., 17: 111-127.

Hochstetter, T. 1998. Horn quality of the bovine hoof under the influence of biotin supplementation. DVM Inaugural Dissertation. Journal \#2176. Free University of Berlin, Germany.

Ingraham, R.H. and Kappel, L.C. 1988. Metabolic profile testing. Vet. Clin. N. Am-Food A., 4: 391.

Johnston, L.A. and Chew, B.P. 1984. Peripartum changes of plasma and milk vitamin $A$ and $\beta$-carotene among dairy cows with or without mastitis. J. Dairy Sci., 67: 1832-1840.

Janovick, N.A., Boisclair, Y.R. and Drackley, J.K. 2011. Prepartum dietary energy intake affects metabolism and health during the periparturient period in primiparous and multiparous Holstein cows. J. Dairy Sci., 94: 1385-1400.

Kilic., Nuh, Ceylan., Ahmet Serin., Ilker. and Gokbulut, Cengiz. 2007. Possible interaction between lameness, fertility, some minerals, and vitamin E in dairy cows. B. Vet. I. Pulawy., 51: $425-429$.

Lawrence, R.J., Elliott R., Norton, B.W., Thoefner, M.B., Loxton I. and Webber, G. 2008. Influence of biotin supplementation on hoof growth and integrity in long-fed F1 Wagyu/Black Angus feedlot steers of known genotype. Austral. J. Exp. Agri., 48(5): 615-620. 
LeBlanc, S.J. 2010. Monitoring metabolic health of dairy cattle in the transition period. J. Reprod. Dev., 56: S29-S35.

Lischer, Ch. J., Hunkeler, A., Geyer H. and Ossent, P. 1996. The effect of biotin in the treatment of uncomplicated claw lesions with exposed corium in dairy cows. Part II: The healing process in supplemented animals. In: Proceeding of $9^{\text {th }}$ International Symposium. Disorders Ruminant Digit Int. Conf. Lameness Cattle at Koret School of Veterinary Medicine, Rehovot, Israel, pp. 31

Maiti, S.K., Parai, T.P. and Nautiyal, L.P. 1996. Incidence of foot disorders in an organized dairy farm. Indian Vet. J., 73: 341-343.

Margerison, J.K., Winkler, B. and Stephens, G. 2002. The effect of locomotion score and lameness and on dry matter intake, feeding and general behaviour. In: Proceedings of XII Inter Symposium on Lameness in Ruminants. January 9-13, Florida, USA, pp. 407-410.

Melendez, P., Bartolome, J., Archbald, L.F. and Donovan, A. 2003. The association between lameness, ovarian cysts and fertility in lactating dairy cows. Theriogenology., 59: 927937.

Midla, L.T., Hoblet, K.H., Weiss, W.P. and Moeschberger, M.L. 1998. Supplemental dietary biotin for prevention of lesions associated with aseptic subclinical laminitis (Pododermatitis aseptic diffusa) in primiparous cows. Am. J. Vet. Res., 59: 733-738.

Minoccheri, F., Germana, G. and Negrini, F. 1977. Diffusion of some vitamins across the placenta in cattle: diffusion of pyridoxine, cobalamin and panthothenic acid. Zootenica Nutrizione Animals., 3: 209-215.

Moore, C.L., Walker, P.M.J., Winter, R., Jones, M.A. and Webb, J.M. 1989. Zinc methionine supplementation for dairy cows. Trans. Illinois. State. Acad. Sci., 82: 99-108.

Moore, D.A., Berry, S.L., Truscott, M.L. and Koziy, V. 2001. Efficacy of a non-antimicrobial cream administered topically for treatment of digital dermatitis in dairy cattle. J. Am. Vet. Med. Assoc., 19: 1435-1438.

Nayeri, A., Upah,N.C., Sucu, E., Sanz Fernandez, M.V., DeFrain J.M., Gorden P.J. and Baumgard, L.H. 2014. Effect of the ratio of zinc amino acid complex to zinc sulfate on the performance of Holstein cows. J. Dairy Sci., 97: 4392-4404.

Nobijaria, H.F. Amanloua, H. and Banadakyb, M.D. 2012. Effects of zinc supplementation on growth performance, blood metabolites and lameness in young Holstein bulls. J. Appl. Anim. Res., 40: 222-228.

Nocek, J.E. 1997. Bovine acidosis: Implications on laminitis. $J$. Dairy Sci., 80: 1005-1028.
NRC. 2001. Nutrient Requirements of Dairy Cattle, $7^{\text {th }}$, Natl. Acad. Press, Washington, DC.

Ospina, P.A., Nydam, D.V., Stokol, T. and Overton, T.R. 2010. Evaluation of non-esterified fatty acids and $\beta$-hydroxybutyrate in transition dairy cattle in the northeastern United States: Critical thresholds for prediction of clinical diseases. J. Dairy Sci., 93: 546-554

Potzsch, C.J., Hedges, V.J., Blowey, R.W., Packington, A.J. and Green, L.E. 2003. The impact of parity and duration of biotin supplementation on white line disease lameness in dairy cattle. J. Dairy Sci., 86(8): 2577-82

Roberts, C.J. and Baggott, D.G. 1982. Biotin experiments with dairy cattle. In: Proceedings of Roche Vitamin Symposium, London, pp. 13-20.

Rowlands, G.J., Lucey, S. and Russell, A.M. 1986. Susceptibility to disease in the dairy cow and its relationship with occurrences of other diseases in the current of preceding lactation. Prev. Vet. Med., 4: 3223-234.

Sharma, Neelesh and Upadhyay, S.R. 2009. Clinical Veterinary Medicine-II. New India Publishing, New Delhi, India.

Shipe, W.F., Senyk, G.F. and Fountain, K.B. 1980. Modified copper soap solvent extraction method for measuring free fatty acids in milk. J. Dairy Sci., 63: 193-198.

Singh, S., Prabhakar, S., Singh, S.S. and Ghumaqn, S.P.S. 1998. Incidence of lameness in dairy cows and buffaloes in Punjab State. Indian Vet. J., 75: 51-53.

Snedecor, G.W. and Cochran,W.G. 1994. Statistical methods, Iowa State University Press, Ames, Iowa, USA, $8^{\text {th }}$ edition.

Sprecher, D.J., Hostetler, D.E. and Kaneene, J.B. 1997. A lameness scoring system that uses posture and gait to predict dairy cattle reproductive performance. Theriology., 47(6): 1179-87.

Van Saun, R.J., Todd, A. and Varga, G.A. 2005. Serum mineral concentrations and risk of periparturient disease. Protocol Am. Assoc. Bov. Pract., 38: 178-179.

Van Saun, R.J. 2006. Metabolic Profiles for Evaluation of the Transition Period. Proc. Am. Assoc. Bov. Pract., 39.

Zhang, Z., Liu, G., Li, X., Gao, L., Guo, C., Wang, H. and Wang. Z. 2010. Evaluation of the change of serum copper and zinc concentrations of dairy cows with subclinical ketosis. Biol. Trace Elem. Res., 138: 8-12.

Zinn, R.A., Owens, F.N., Stuart, R.L., Dunbar, J.R. and Norman, B.B. 1987. B-Vitamin supplementation of diets for feedlot calves. J. Animal Sci., 65: 267-77. 